\title{
ATTEMPT OF SOCIAL STRATIFICATION OF THE SOUTHERN VIMINACIUM CEMETERIES ACCORDING TO PALEOPATHOLOGICAL CATEGORIES
}

\begin{abstract}
An attempt to compare the number of anthropologically studied skeletons and the number of paleopathological diagnoses noted on them from the cemeteries of Pecine and Više Grobalja, which both actually represent a common, southern Viminacium cemetery, offered actual data in the sense of society's social stratification. From the Pećine cemetery, 4,312 skeletons have been studied and 149 diagnoses established (3.36\%). The Više Grobalja cemetery showed a different ratio: 1,574 skeletons with 219 diagnoses $(13.91 \%)$. These results indicate that the individuals buried in the eastern part of the southern cemetery were in worse health compared to those from the western part of the same cemetery.
\end{abstract}

\section{KEYWORDS:VIMINACIUM,SKELETONSFROMTHEROMANPERIOD,PALEOPATHOLOGICALCA- TEGORIES, PERCENTUALRELATION OF DIAGNOSES, HEALTH PROFILE, ELEMENTS OFTHE SO- CIETY'S SOCIAL STRATIFICATION.}

\section{INTRODUCTION ${ }^{1}$}

During the archaeological research and according to the cadastre books, the southern Viminacium cemeteries were divided into two sites: Pećine and Više Grobalja. In 1977, the Pećine excavation started and ended in 1988. During that period, 5,440 graves were unearthed.

Between 1984 and 1986, the site of Više

1 The article results from the project: IRS - Viminacium, Roman city and military legion camp - research of the material and non material culture of inhabitants by using the modern technologies of remote detection, geophysics, GIS, digitalisation and $3 D$ visualisation (no 47018), funded by the Ministry of Education, Science and Technological Development of the Republic of Serbia.
Grobalja was excavated. During that period, 2,183 graves were unearthed. It needs to be mentioned that the skeletons numerated 1 to 162 were not included in the anthropological study (Mikić 1984).

It is known that Viminacium was both a legionary fort and a civilian settlement, actually a city. Since, according to archaeological criteria, it was not possible to separate the military from the civilian Viminacium necropolis (or necropolis parts), we tried to make a division according to the health criteria, in order to understand the differences in some other aspects. - The author considers that the social stratification of the buried Viminacium inhabitants could be determined according to paleopathological elements. The reason lies in the fact that not all of the Viminacium 
inhabitants suffered from same diseases in the same period. The importance of such a hypothesis must be based primarily on the most common diseases and not on those appearing only in a small number, or sporadically (bone diseases, treponematoses (eg. male skeleton nr. 1651/b from Pećine etc.).

\section{MATERIAL AND METHOD}

In spite of the well conducted archaeological research, the preservation degree of the Viminacium skeletons was not high. Because of this, at the Pećine necropolis, due to the very poor and incomplete state of preservation, 1,075 grave contents suitable for anthropological analysis were not lifted from the graves. In addition to this, 27 skeletons were chronologically ascribed to the Middle Ages (marked as $\mathrm{G}_{4}$ ), whilst an additional 26 graves were ascribed to the prehistoric Celts (marked as $\mathrm{G}_{3}$ ). This, therefore, results in the fact that the anthropological analysis was performed on 4,312 graves from the Roman period.

In 1988, the necropolis at Više Grobalja included 2,183 graves. Graves 1 to 162 were not used for the anthropological study, along with 329 graves whose content was not lifted due to the previously mentioned reasons. Another 120 skeletons from this location were ascribed to the period of the Great Migration (marked as $\mathrm{G}_{2}$ ), therefore resulting in the fact that the analysis was performed on 1,574 graves from the Roman period.

The starting point for this attempt of social stratification of the southern Viminacium cemeteries, archaeologically excavated and documented as the cemeteries of Pećine and Više Grobalja, is based on a total of 5,886 graves from the Roman period. As mentioned, these include 4,312 graves from the Pećine cemetery and 1,574 graves from the Više Grobalja cemetery (Korać i Golubović, 2009).

The paleopathological study method of the human osteological material from Viminacium was primarily macroscopic. Only about $1 \%$ of the established diagnoses were radiologically documented, including only very rare and specific finds which do not directly fit into the title of this paper. All of the paleopathological diagnoses were categorised according to pathological handbooks, written by G.T. Steinbeck (1976), A.C. Aufderheide and C. Rodrigez-Martin (1998) and D. J. Ortner (2003). Our previous experience was also used. This included the Atlas written by A. Lovrinčević and Ž. Mikić (1989), as well as the paleopathological handbook by E. Hoševski and Ž. Mikić (1995).

All of the radiological recordings were conducted earlier, in the clinical centre of the Radiological Institute in Sarajevo, at the same time that the Atlas by A. Lovrinčević and Ž. Mikić was prepared. Since a certain number of paleopathological finds from Viminacium have been kept and preserved up to the present day, there is a possibility to conduct the latest microscopic and molecular analyses. Such finds are specific and they would surely be indicative, both for the development and application of further methodology, as well as for the Roman city and the legionary fort of Viminacium.

The photographic documentation from Viminacium which is at our disposal will be presented here only in a limited number, mostly in order to avoid unnecessary repetition of the already partially published material. It should, once again, be stressed that this paper should result in a social stratification of the individuals buried at the southern Viminacium cemeteries, all of which is based on the examined paleopathological categories.

\section{RESULTS}

After examining the huge amount of anthropological documentation of almost six thousand $(5,886)$ skeletons from the Roman period, the results are presented in Table 1. This shows all the discovered paleopathological diagnoses in the order determined from the number of finds, since 


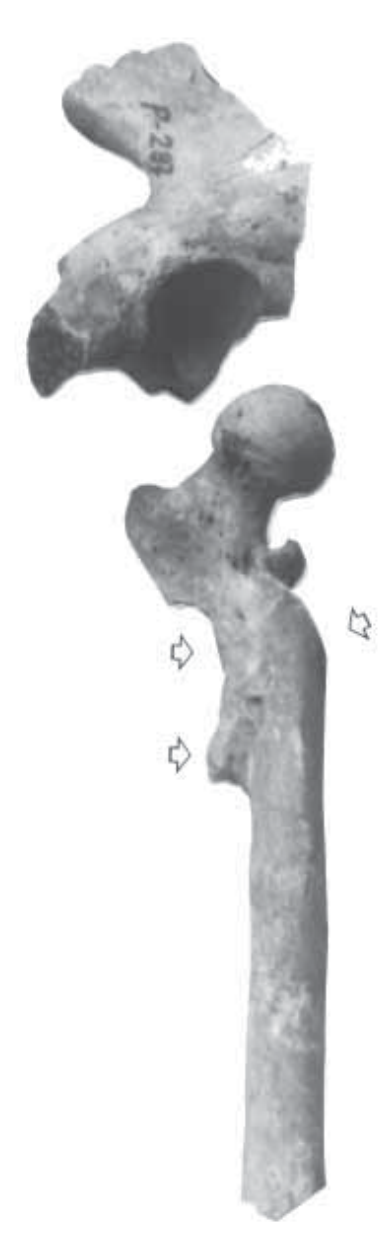

Viminacium, Pećine No. 297

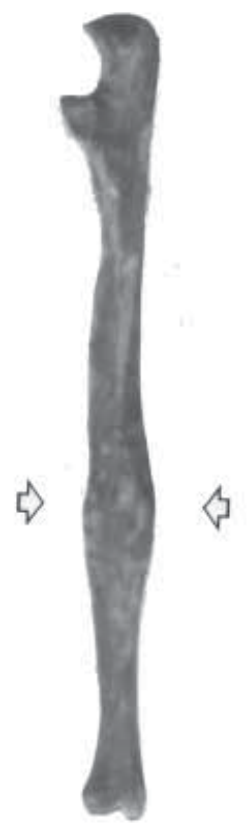

Viminacium, Više grobalja No. 197 we consider this best matches with the title of the paper. As the table shows, apart from the cranial and post-cranial skeleton parts, jaws and teeth were also considered, as a part of each skeletal individual. Trepanning is also listed in the table, since it most directly indicates the state of medical treatment in Viminacium (Mikić 2006).

What needs to be mentioned is that with such a large number of samples, diagnoses that appear on less than ten, again subordinated to the title of the paper, shall not be considered. However, all of them were noted. This refers to periodontitis of a very high degree, specific contagious diseases (treponematoses), osteoporosis senilis and bone tumours (noted on skulls only).

The most numerous paleopathological observations regard the jaws and teeth, with caries, tooth loss intra vitam and the accompanying cysts (peridentisis periapicalis chronica granulomatesa).

At the Pecine necropolis, with 40 cases, the frequency of caries and loss of teeth caused by it, does not even reach one percent $(0.93 \%)$, whilst at the Više Grobalja necropolis, with 105 cases, it reaches $6.67 \%$.

Dental cysts on the jaws from the Pećine necropolis (17 cases), compared with previous finds, show an even smaller percentage $-0.39 \%$. At the Više Grobalja cemetery, with 32 cases, this percentage climbs to $2(2.03 \%)$.

In Viminacium, accidental traumas always occur on the post-cranial part. In the greatest number of cases, there are healed fractures (status post fracturam) of the long bones. The accuracy of sanation was not always of a high level and many different cases were discovered. The first case of a badly healed femur fracture at the Pećine necropolis was observed on skeleton number 279 (female, up to 40 years). This case was photographed by the author and is depicted in the annex, as Figure 1.

The first fracture noted at the Više Grobalja necropolis was on skeleton number 197 (male, over 40 years of age). The healed fracture of his ulna was also depicted in Figure 1. 


\begin{tabular}{|c|c|c|}
\hline $\begin{array}{c}\text { Site } \\
\text { Number of examined skeletons }\end{array}$ & $\begin{array}{l}\text { Pećine } \\
4,312\end{array}$ & $\begin{array}{c}\text { Više Grobalja } \\
1,574\end{array}$ \\
\hline \multicolumn{3}{|l|}{ JAWS AND TEETH } \\
\hline Caries - intra vitam tooth loss & 40 & 105 \\
\hline Dental cysts & 17 & 32 \\
\hline Periodontitis (of a developed degree) & 6 & 7 \\
\hline \multicolumn{3}{|l|}{ TRAUMAS } \\
\hline Accidental traumas - status post fracturam & 33 & 14 \\
\hline Deliberate traumas (Causa mortis - amputation) & 5 & 9 \\
\hline \multicolumn{3}{|l|}{ RHEUMATIC CHANGES } \\
\hline Regardless of location & 21 & 24 \\
\hline \multicolumn{3}{|l|}{ UNSPECIFIC CONTAGEOUS DISEASES } \\
\hline Poriostitis - osteomielitis & 10 & 10 \\
\hline \multicolumn{3}{|l|}{ SPECIFIC CONTAGEOUS DISEASES } \\
\hline Treponematoses & 2 & $1 / 2$ \\
\hline \multicolumn{3}{|l|}{ METABOLIC DISEASES } \\
\hline Cribra orbitalia & 8 & 13 \\
\hline Osteoporosis senilis & 3 & 1 \\
\hline \multicolumn{3}{|l|}{ TUMORS } \\
\hline Osteomas on skull & 3 & 1 \\
\hline SKULL TREPANNING & 1 & $2 / 1$ \\
\hline Total of paleopathological diagnoses & 149 & 219 \\
\hline Percentage of the total number of diagnoses & $3.46 \%$ & $13.91 \%$ \\
\hline
\end{tabular}

Table 1: Tabelar display of paleopathological diagnoses of the southern Viminacium cemeteries categorised according to the number of specific cases

In Viminacium, deliberate traumas always relate to the skull (Korać i Mikić, 2012). One exception is an amputation noted on male skeleton number 1226/D from the Više Grobalja necropolis, where the lowest part of the left ulna (towards the wrist) is missing. The biggest part that remained is slightly rounded and therefore healed, with an obvious reduced length (about $2 \mathrm{~cm}$ ). However, since there were other paleopathological changes noted on this skeleton, it is quite possible that an intervention "due to surgical reasons" was performed. A separate and expert publication of skeleton number 1226/D will follow, exactly because of the paleopathological changes on its bones.

At the Pećine necropolis, accidental traumas were noted on 33 skeletons, representing a total of $0.77 \%$ of the number examined. On the other hand, at the Više Grobalja necropolis, there were 14 skeletons with healed fractures of long bones, a total of $0.89 \%$ of the number examined. 


\begin{tabular}{|c|c|c|}
\hline $\begin{array}{c}\text { Site } \\
\text { Number of examined skeletons }\end{array}$ & $\begin{array}{l}\text { Više grobalja } \\
1,574\end{array}$ & $\begin{array}{l}\text { Pećine } \\
4,312\end{array}$ \\
\hline \multicolumn{3}{|l|}{ JAWS AND TEETH } \\
\hline Caries - intra vitam teeth loss & $6.67 \%$ & $0.93 \%$ \\
\hline Dental cysts & $2.03 \%$ & $0.39 \%$ \\
\hline \multicolumn{3}{|l|}{ TRAUMAS } \\
\hline Accidental - status post fracturam & $0.89 \%$ & $0.77 \%$ \\
\hline Deliberate - causa mortis & $0.57 \%$ & $0.12 \%$ \\
\hline \multicolumn{3}{|l|}{ RHEUMATIC CHANGES } \\
\hline Regardless of location & $1.52 \%$ & $0.49 \%$ \\
\hline \multicolumn{3}{|l|}{ UNSPECIFIC CONTAGEOUS DISEASES } \\
\hline Poriostitis - osteomielitis & $0.64 \%$ & $0.23 \%$ \\
\hline \multicolumn{3}{|l|}{ METABOLIC DISEASES } \\
\hline Cribra orbitalia & $0.83 \%$ & $0.19 \%$ \\
\hline $\begin{array}{l}\text { Percentage of the total number of diagnoses } \\
\text { (according to the number of examined skeletons) }\end{array}$ & $3.46 \%$ & $13.91 \%$ \\
\hline
\end{tabular}

Table 2: Percentual relation of the most numerous number of paleopathological diagnoses according to the number of specific cases

Deliberate traumas always relate to the skull in all the noted cases. The Pećine necropolis revealed five such cases, while the Više Grobalja necropolis revealed nine cases. This is $0.12 \%$ in Pećine and $0.57 \%$ in Više Grobalja.

Rheumatic diseases were noted on different skeleton parts - at the Pećine necropolis, they were noted in 21 cases, or $0.49 \%$. On the Više Grobalja necropolis, this number is 24 , or $1.52 \%$ (compared to the total number of examined skeletons).

As shown in Table 1, at both of the cemeteries, unspecific contagious diseases were noted in ten cases each. Compared to the total number of skeletons, at the Pećine necropolis, this is $0.23 \%$, while at the Više Grobalja necropolis, this is $0.64 \%$.

When it comes to the specific contagious diseases of the inhabitants of Roman Viminacium, only three cases of trepomenathosis were noted. Two of them were discovered on the skeletons from the Pećine necropolis and only one from the Više Grobalja cemetery.

Metabolic diseases, primarily cribra orbitalia, were noted on the buried at both of the cemeteries. At the Pećine necropolis, it occurs only on infant skeletons, in eight cases $(0.19 \%)$. The Više Grobalja necropolis revealed thirteen cases $(0.83 \%)$, both on infant, as well as female skeletons (see Table 2).

Osteoporosis senilis (parietalis), categorised into the same paleopathological group, was noted in only four cases. Three occur on finds from the Pećine necropolis and only one on a skull from the Više Grobalja necropolis.

Tumours, or osteomata, were noted on three skulls from the Pećine necropolis and only on one skull from the Više Grobalja necropolis.

Due to the already mentioned reasons, trepanning was included into Table 1, but does not offer any significant results. There are three cases 
from both of the cemeteries. What is typical is the application of an older trepanning technique scraping. Trepanning using the so-called piercing technique (using a suitable metal piercer - trepanner), which is certainly chronologically younger and would have been easier for the "patient", was not noted on the studied anthropological material from Viminacium.

\section{DISCUSSION}

The discussion relevant for the title of this paper and its content refers only to skull number 1651/B. In 1995, it was published (Hošovski and Mikić 1995) and illustrated (p. 151, T. XVI), with the conclusion that it represents syphilis with significant periostal sediments. Some ten years later (Mikić 2006), after comparing similar published finds, the author regarded this as an interrupted trepanning. It is sufficient to compare it to the previous case from the same Viminacium necropolis - Više Grobalja number 1037, in order to conclude that the positioning is practically the same (at the arch of the left parietal and occipital bone), the same technique was applied (scraping the outer bone cover), while the surface included in the "scraping" is slightly bigger and is clearly visible. The "surgeon" did not reach the outer brain membrane (Dura matris), while the intervention zone is only slightly bigger compared to the previous case of trepanning (number 1037). The newly formed irregular osteoblast conglomerations certainly reveal bone healing, still leaving the possibility open that there might have been certain infections which influenced the appearance of the new bone surface.

\section{CONCLUSION}

According to our results, the disproportion of the archaeologically excavated human osteological material from all of the cemeteries that are included in the southern Viminacium necropolis $(4,312: 1,547$ skeletons), gave priority to the percentage ratios of the highlighted paleopathological categories. Our attempt of social stratification will actually be based on these percentage ratios between the Više Grobalja and the Pećine cemeteries (see Table 2).

It should be emphasised that, although the number of examined skeletons from the Više Grobalja necropolis was about 2/3 smaller, there is always a much larger percentage of paleopathological diagnoses compared to the Pećine necropolis. This primarily relates to jaws and teeth $(6.67 \%$ : $0.93 \%$, actually $2.03 \%: 0.39 \%$ ). Rheumatic diseases show a ratio of $1.52 \%: 0.48 \%$. Both trauma categories reveal the same image $(0.89 \%: 0.77 \%$, actually $0.57 \%: 0.12 \%)$. - The same ratio shows with unspecific and specific contagious diseases, as well as with metabolic diseases (Grupe 1995).

The frequency percentage of paleopathological diagnoses is much higher with the individuals buried at the Više Grobalja necropolis, compared to those buried at the Pećine necropolis. A similar situation is seen with tumours, noted only on skull bones.

When it comes to skull trepanning, as already explained in this paper, each necropolis possesses one case, a total of two cases, among its discoveries. Until now, the site at Pirivoj, basically representing the eastern Viminacium cemetery, possesses five skulls with trepanning, which were recently published (Kirilenko and Mikić 2014).

Generally speaking, we will not discuss paleopathological diagnoses, parallel diagnoses and their ethiologies, since everything is subordinated to the title of the paper: The attempt of social stratification according to paleopathological categories, actually diagnoses frequencies according to the number of the buried at each of the cem- 
eteries. Also, according to archaeological criteria (Korać and Golubović 2013), it transpired that the cemeteries at Pećine and Više Grobalja spatially form the southern Viminacium cemetery, separated due to the cadastre division of the areas included, and this is how the graves and skeletons were excavated and numerated.

Geographically, the part of the southern cemetery named Pećine was situated somewhat to the west and closer to the city, which can clearly be seen on the spatial plan of Viminacium. The part of the same necropolis named Više Grobalja, was situated to the east and most likely included the sites of Velika Kapija and Carine (excavated only partially).

The parallel analysis of paleopathological diagnoses performed in this paper show two basic results. The first indicates that the western part (Pećine) revealed a smaller number of diagnoses (149). The eastern part of the southern necropolis (Više Grobalja) possesses a larger number of diagnoses (219), with the number of the examined skeletons about $2 / 3$ smaller (see the tables). - Basically, the population buried in the western part possessed a proportionally better health profile compared to the Viminacium inhabitants buried in the eastern part of the southern necropolis. - Precisely this is the most important indicator regarding the existence of social stratification within the population of Roman Viminacium. It shows not only in the archaeological data (according to the field diary), but also in health status, which differs significantly from one necropolis to the other.

Another conclusion, regarding the total of the results gained, indicates that this was "a very vital population". With this conclusion, one should consider the importance of Viminacium as a city and a legionary fort.

There are certainly elements of criticism regarding the method applied and the conclusions drawn. In the first place, it is the lack of the graves', or the skeletons' stratigraphy, but this will be considered in one of the future archaeological projects. In one of the further phases, this context should also include the eastern, Pirivoj necropolis, at which there was the imperial mausoleum etc. It is considered that to the west and the north of the city, there were no geo-morphological conditions for cemeteries. However, what remains is a successful attempt of social stratification of the inhabitants of a huge urban Roman settlement, based on the ratios of pathological diagnoses that left their destructive mark on solid soil, and the number of anthropologically examined skeletons within a known chronological span.

\section{BIBLIOGRAPHY}

Aufderheide, A.C. and Rodrigez-Martin, C.
1998 The Cambridge Encyclopedia of Human Paleopathology, Cabridge: Cambridge University Press.

\section{Grupe, G. 1995}

Zur Ätilogie der Cribra orbitalia: Auswirkungen auf das Aminosäurenprofil im Knochenkollagen und den Eisengehalt des Knochenminerales. Zeitschrift für Morphologische Anthropologie 81/1: 125-137.

\section{Hošovski, E. and Mikić, Ž. 1995}

Paleopatologija čoveka ilustrovana nalazima sa područja centralnog Balkana, Užice: Narodni muzej u Užicu.

\section{Кириченко, Д. А., Микич, И. Ж. 2014}

Случаи трепанации черепа с территории римского мавзолея III-IV вв. г. Виминаций, Актуальная археология 2. Археология в современном мире: в контакте и в конфликте, Санкт Петербург: 80-85.

\section{Korać, M. and Golubović, S. 2009}

Viminacium - Više grobalja 2, Beograd: Arheološki institut. 
Korać, N. and Mikić, I. 2012

Finds of Causa Mortis on the Skeletons at Viminacium in Context of Amphitheatre Discoveries, Archaeology and Science 7: 339-352.

Lovrinčević, A. and Mikić, Ž. 1989

Atlas of osteopathological changes of the historical Yugoslav populations, Sarajevo: Svjetlost.

\section{Mikić, Ž. 1984}

Beitrag zur Anthropologie spätrömischer bis zum spätmittelalterlicher Bevölkerungen Jugoslawiens, Godišnjak XXII/20 Centra za balkanološka ispitivanja ANUBiH: 1-101.

Mikić, Ž. 2006

Trepanacija lobanja na antičkom Viminacijumu antropološke informacije. Arheologija i prirodne nauke 1: 9-20.

Ortner, D. J. 2003

Identification of Pathological Conditions in Human Skeletal Remains, Amsterdam, Boston, London, New York, Tokyo: Academic Press.

Steinbuck, G. T. 1976

Paleopathological Diagnosis and Interpretations, Bone Diseases in Ancient Human Populations, Springfield: Charles C. Thomas.

\section{REZIME}

POKUŠAJ SOCIJALNE STRATIFIKACIJE JUŽNIH NEKROPOLA VIMINACIJUMA NA OSNOVU PALEOPATOLOŠKIH KATEGORIJA

KLJUČNE REČI: VIMINACIUM, SKELETI IZ RIMSKOG PERIODA, PALEOPATILOŠKE KATEGORIJE, PERCENTUAL RELATION OF DIAGNOSES, ZDRAVSTVENI PROFIL, ELEMENTI SOCIJALNE STRATIFIKACIJE.
Prilog predstavlja specifičan pokušaj da se na primeru južnih nekropola Viminacijuma, koje su tokom arheoloških iskopavanja imenovane po katastarskim kriterijumima kao «PEĆINE» i «VIŠE GROBALJA», pomoću uporedne statističke analize dijagnostifikovanih paleopatoloških kategorija sagleda socijalna stratifikacija sahranjenih pretežno u periodu od II do IV veka nove ere. Te paleopatološke kategorije su: promene na aparatu vilica i zuba, zatim traume, reumatske promene, nespecifične i specifične zarazne bolesti, metaboličke bolesti i tumori. U obzir su uzete i trepanacije lobanja, koje su svakako odraz lekarstva, konkretno iz Viminacijuma.

Iz nekropole PEĆINE antropološki je pregledano 4312 skeleta i konstatovano 149 dijagnoza (što iznosi 3,46\%). Iz nekropole VIŠE GROBALJA pregledano je 1574 skeleta na kojima je uočeno 219 patoloških promena, što predstavlja 13,91\% (videti tabele 1 i 2).

Upoređeni rezultati nekropole PEĆINE (4312 skeleta sa 149 dijagnoza) i nekropole VIŠE GROBALJA (1574 skeleta sa 219 dijagnoza) jasno pokazuju da je u istočnom delu jedinstvene južne nekropole Viminacijuma bilo sahranjivano stanovništvo slabijeg zdravstvenog statusa. Zapadni deo južne nekropole PEĆINE je sadržavao, prema našoj analizi, skelete žitelja ovog antičkog lokaliteta koji su imali znatno bolji zdravstveni profil. Dobijen je egzaktan pokazatelj o postojanju socijalne stratigrafije stanovništva Viminacijuma, a koji se manifestuje i u određenim lokacijama unutar velike i jedinstvene južne nekropole. 


\section{ADDENDUM I}

Pećine necropolis ( $\mathrm{M}$ - male, $\mathrm{F}$ - female, $\mathrm{N}$ - infant, $\mathrm{n}$ - unidentified gender)

Caries and intra vitam tooth loss: number and skeleton gender:

385(F), 445(M), 455(F), 457(F), 459(F), 473(M), 479(M), 1002(F), 1048(M), 1055(N), 1068(M), 1106(M), 1123(M), 1305(M), 1352(M), 1359(M), 1566(M), 1570(M), 1584(M), 1603(M), 1677(M), 1684(M), 1688(M), 1690(M), 1691(M), 1876(F), 1986(M), 2004(M), 2050(M), 2113(M), 2201(F), 2317(F), 2372(M), 2428(M), 2432(M), 2503(M), 2507(M), 2568(M), 2569(F) and 2625(M).

\section{Dental cysts:}

445(M), 1068(M), 1110(M), 1352(M), 1359(M), 1566(M), 1677(M), 1684(M), 1688(M), 1876(F), 1986(M), 2113(M), 2317(F), 2372(M), 2428(M), 2503(M) and 2625(M).

Parodontitis (of a developed degree):

455(F), 1305(M), 2050(M), 2317(F), 2428(M) and 2432(M).

\section{Accidental traumas:}

297(M), 405(F), 458(F), 474(N), 476(M), 486(F), 1399(F), 1471(M), 1524(M), 1560(F), 1562(M), 1584(M), 1590(M), 1710(M), 1869(M), 1957(M), 2056(M), 2079(M), 2096(M), 2357(M), 2412(N), 2697(M), 2759(M), 2764(M), 2786(M), 2980(M), 3010(M), 3251(M), 3304(M), 3328(M), 3428(M) and $3518(\mathrm{M})$.

\section{Deliberate traumas:}

1587(M), 2158/B(M), 3155(M), 3260/A(M) and 3260/B(M).

\section{Rheumatic changes:}

432(M), 1071(M), 1380(M), 1381(F), 1569(M), 1471(M), 1723(N), 1994(M), 2286(F), 2295(F), 2361(F), 2373(M), 2467(M), 2666(M), 2716(F), 2786(M), 3052(M), 3183(M), 3347(F) and
3524(M).

\section{Unspecific contagious diseases:}

357(M), 386(F), 410(M), 426(N), 1071(M), 1431(F), 1444(M), 1687(M), 3368(F) and 3430(M).

\section{Specific contagious diseases:}

1624(M) and 1699(F).

\section{Cribra orbitalia:}

1003(N), 1347(N), 1536(N), 1784(N), 1976(N), 2191(N), 2279(N) and 3396(N).

\section{Bone tumours:}

2164(M), 2509(M) and 2882(M).

\section{Trepanning:}

2570(M).

\section{ADDENDUM II}

Više Grobalja necropolis ( $\mathrm{M}$ - male, F - female, $\mathrm{N}$ - infant, $\mathrm{n}$ - unidentified gender)

Caries and intra vitam tooth loss: number and skeleton gender:

166(M), 172(M), 187(M), 208(F), 246(M), 301(M), 327(F), 343(M), 347(F), 359(M), 367(F), 367/A(F), 369(M), 369/A(M), 385(M), 455(M), 457(M), 468(M), 477(F), 489(F), 493(M), 527(M), 527/A(M), 543(M), 543/A(M), 575(F), 579(M), 589(M), 594(F), 595(M), 596(F), 617(M), 637(M), 655(M), 683(F), 688(F), 694(M), 698(M), 698/A(M), 707(F), 710(M), 718(F), 736(F), 745(M), 756(M),772(M),773(M), 774(M), 780 (F), $782(\mathrm{M}), 788(\mathrm{~F}), 827$ (M), $850(\mathrm{M}), 851(\mathrm{~F}), 860(\mathrm{M}), 861(\mathrm{~F}), 872(\mathrm{M})$, 876 (M), 892 (M), 908/A(M), 908/B(F), 915(F), 916(M), 933M), 934(F), 942(M), 948(M), 959(F), 962(M), 981(M), 987(M), 998/A(M), 1006(M), 1007(F), 1009(M), 1017(M), 1026(M), 1035(M), 1039(F), 1048(F), 1050(F), 1052(M), 1053(M), 
1057/A(M), 1058(M), 1074(F), 1086(M), 418(N), 588(F), 669(N), 683(F), 983(N), 1131(N), 1094(M), 1099(M), 1110(M), 1114(M), 1115(M), 1156(N) and 1191(N).

1118(M), 1120(F), 1128(M), 1132(F), 1133(M), 1136(F), 1137(F), 1138(M), 1145(F), 1146(M), 1247(M), 1340(F) and 1442(F).

\section{Osteoporosis senilis:}

228(F).

\section{Dental cysts:}

209(F), 343(M), 367(F), 369(M), 493(M), 543(M), 579(M), 594(F), 595(M), 617(M), 694(M),

717(F), 736(F), 745(M), 756(M), 774(M), 851(F), 872(M), 876(M), 892(M), 908/B(F), 915(F), 916(M), 942(M), 987(M), 998/A(M), 1026(M), 1039(F), 1053(M), 1114(M), 1132(F) and 1136(F).

Parodontitis (of a developed degree):

213(M), 655(M), 713(M), 718(F), 771(M), 774(M) and 1098(F).

\section{Accidental traumas:}

197(M), 301(M), 325(M), 593(M), 651(M), 690(M), 756(M), 916(M), 1031(M), 1184(M), 1213(M), 1479(M), 1783(M) and 1843(M).

\section{Deliberate traumas:}

186(F), 257(M), 469(M), 527(M), 565(M), 594(F), 742(M), 1163(M) and 1510/B(M).

\section{Rheumatic changes:}

246(M), 266(M), 319(M), 527(M), 588(F), 600(M), 668(M), 707(F), 713(M), 743(M), 746(M), 746/D(M), 780(F), 794(F), 826(M), 935(F), 969(M), 990(M), 996(M), 1052(M), 1134(M), 1136(F), 1156(M) and 1168(F).

\section{Unspecific contagious diseases:}

162(N), 190(M), 205(F), 213(M), 319(M), 390(M), 593(M), 1226(M), 2112/B(M) and 2112/C(M).

\section{Specific contagious diseases:}

1651/B(M) and 1651/E(M).

\section{Cibra orbitalia:}

166/A(N), 199(N), 228(F), 262(N), 264(F),

\section{Bone tumours:}

359(M).

\section{Trepanning:}

1033(M) and 1161/B(M), first it was published as a syphilitic changes, and then found that it was initiated and discontinued trepanation (which was not the immediate cause of death of the skeletal individual). 